\title{
Malaria control in an Amazon municipality ${ }^{1}$
}

\author{
Eliane da Costa Rodrigues ${ }^{2}$ \\ David Lopes Neto ${ }^{3}$
}

This study aimed to evaluate the organization of malaria control actions in the Indigenous population of the municipality of São Gabriel da Cachoeira, Amazonas, AM, Brazil, from 2003 to 2007. This is an ecological study to evaluate the impact of control measures. Statistical analysis of the indicators revealed that the number of cases showed an increasing trend, with the highest numbers occurring in the rural areas. The same trend was observed for the Annual Parasite Index (API), however the highest APIs were found in the urban areas. The proportion of cases caused by Plasmodium falciparum showed a reduction. Hospitalization and mortality rates presented fluctuations and the fatality rate decreased. The findings indicate that control actions have proved partially effective and that they have provided a broader capacity to detect cases and to provide immediate treatment. Although the municipality still presents a high risk for transmission, the Pluriannual Plan in progress seems to have a good prognosis for the control of the disease, if maintained in a sustainable and permanent way.

Descriptors: Malaria; Indigenous Health; National Health Programs.

\footnotetext{
${ }^{1}$ Paper extracted from Master's Dissertation "Avaliação das ações de controle da malária em indígenas de São Gabriel da CachoeiraAmazonas, no período de 2003 a 2007" presented to Escola de Enfermagem, Universidade Federal do Amazonas, AM, Brazil. Supported by Fundação de Amparo à Pesquisa do Estado do Amazonas and by Coordenação de Aperfeiçoamento de Pessoal de Nível Superior (FAPEAM/CAPES), process \# 2375/200.

2 RN, M.Sc. in Tropical Pathology. E-mail: elianecr@ufam.edu.br.

${ }^{3}$ RN, Ph.D. in Nursing, Adjunct Professor, Escola de Enfermagem, Universidade Federal do Amazonas, AM, Brazil. E-mail: davidnetto@ufam.edu.br.
}

Corresponding Author:

Eliane da Costa Rodrigues

Rua Vicência, 122

Bairro: São Gabriel

CEP: 31985-130, Belo Horizonte, MG, Brasil

E-mail: elianecr@ufam.edu.br 


\section{Controle da malária em um município amazônico}

Este estudo objetiva avaliar a organização das ações de controle da malária em populações indígenas do município de São Gabriel da Cachoeira, Amazonas, AM, Brasil, no período de 2003 a 2007. Trata-se de estudo ecológico, de avaliação do impacto de medidas de controle. A análise estatística dos indicadores revelou o número de casos, mostrando tendência crescente, os maiores números ocorrendo na área rural. Mesma tendência observada pela incidência parasitária anual (IPA); entretanto, as maiores IPA verificaram-se na área urbana. A proporção de casos por Plasmodium falciparum mostrou redução. Taxas de internação e mortalidade apresentaram oscilações e a taxa de letalidade, decréscimo. Os achados indicam que as ações de controle mostraram-se parcialmente efetivas, assim como proporcionaram capacidade de detecção mais ampla de casos e tratamento imediato. Apesar de o município ainda apresentar alto risco para transmissão, o plano plurianual em andamento parece ter bom prognóstico quanto ao controle da doença, se mantido de forma sustentável e permanente.

Descritores: Malária; Saúde Indígena; Planos e Programas de Saúde.

\section{Control de la malaria en un municipio amazónico}

Este estudio objetiva evaluar la organización de las acciones de control de la malaria en indígenas del municipio de Sao Gabriel de la Cachoeira, en el estado Amazonas (MA), en Brasil, en el período de 2.003 a 2.007. Se trata de un estudio ecológico, de evaluación del impacto de medidas de control. El análisis estadístico de los indicadores reveló el número de casos mostrando una tendencia creciente, los mayores números ocurrieron en el área rural. La misma tendencia fue observada para la Incidencia Parasitaria Anual (IPA), entre tanto las mayores IPA se verificaron en el área urbana. La proporción de casos por Plasmodium falciparum mostró una reducción. Las tasas de internación y mortalidad presentaron oscilaciones y la tasa de letalidad una disminución. Los resultados indican que las acciones de control se mostraron parcialmente efectivas, así como proporcionaron una capacidad de detección más amplia de casos y tratamiento inmediato. A pesar de que el municipio todavía presenta alto riesgo para transmisión, el Plan Plurianual en andamiento parece tener buen pronóstico en el control de la enfermedad, manteniéndose de forma sustentable y permanente.

Descriptores: Malaria; Salud Indígena; Programas de Salud Nacionales.

\section{Introduction}

Malaria is a disease that, although old, still represents a serious worldwide public health problem, being one of the major tropical parasitic diseases, affecting about 500 million people and causing one million deaths every year. The disease occurs mainly in the tropical and subtropical zones, such as parts of the Americas, Asia and Africa(1). In Brazil, the area of the greatest endemicity is the Amazon, presenting $99 \%$ of cases, due to conditioning and determining factors ${ }^{(2-4)}$, i.e. favorable to the spread of disease, such as: temperature, humidity, altitude and vegetation, which make the environment conducive for the proliferation of the mosquito vector, in addition to the living and working conditions of local people ${ }^{(5)}$. There is a marked indigenous presence in the region, concentrating more than $50 \%$ of the population of Brazil, especially in the extreme northwest of Amazonas, where the city of São Gabriel da Cachoeira is located, the largest center of indigenous people in the country. Malaria is one of the main diseases responsible for the high morbidity and mortality of the indigenous people of $\mathrm{Brazil}^{(6-7)}$. 
Given the high Annual Parasite Index (API) in the Amazon, in 2000 the Government launched the Plan for the Intensification of Actions for the Control of Malaria (PIACM) as part of the overall strategy to combat this disease, aiming to reduce it in the Amazon region from 31.9 cases/thousand to $18.8^{(8-9)}$. In 2003, the National Malaria Prevention and Control Program (NMPCP) emerged as a permanent policy for the prevention and control of the disease, to continue the progress made with the PIACM(10). Given these facts, the following guiding questions were raised: how are the actions specific to malaria in indigenous healthcare organized? Was there a reduction in the rates of hospitalization and mortality due to this disease in the indigenous population, after the implementation of the NMPCP, in the period 2003 to 2007? What was the API of malaria in the indigenous population during the years listed above, and what was the percentage of disease caused by Plasmodium falciparum, the etiologic agent that causes the most severe form of malaria?

This study was relevant and opportune, because, to evaluate the organizational aspect of the actions in the evolution of the indicators regarding malaria in the period could provide a valuable contribution to the referred program by providing information and scientific data that may serve as support to reformulate or improve their actions within the context of the public service of the municipality. In this way these actions can be made more appropriate for a population in which malaria is responsible for higher rates of incidence and mortality, considering that the information is essential for epidemiological surveillance and provides a basis for action, tailoring resources and services to meet the health needs of the population(3). The aim of this study was to evaluate the organization of the actions to control malaria in the indigenous population of the municipality of São Gabriel da Cachoeira, Amazonas State, in the period from 2003 to 2007.

\section{Methods}

This is an ecological study, performed between 2003 and 2007, using descriptive analysis of a population of a given geographical area through evaluation of the impact of measures to control malaria in the indigenous population in the municipality of São Gabriel da Cachoeira, Amazonas state, northern Brazil. The municipality has a population of 39,130 inhabitants and is home to 22 ethnic groups who speak over 20 languages, with about $90 \%$ of the total population of the municipality being from one these ethnic groups ${ }^{(11-}$ 12). With regard to malaria control, in relation to the actions of the NMPCP in Sao Gabriel da Cachoeira, there was a decrease in the time for diagnosis and treatment, mainly due to the deployment of the diagnostic network, which will be expanded further. The information system is updated weekly and a monthly report is sent to the Ministry of Health.

In this evaluation study the effects of the intervention were considered, not only for the individuals who benefited from it, but also for the entire population to whom it was intended (population effectiveness), considering evaluative research as a guiding component of public health practices ${ }^{(13)}$. To perform the evaluation, the following impact indicators were used: number of malaria cases per year (absolute number of positive slides for malaria/year); Annual Parasite Index (API) (number of positive slides for malaria/year per thousand inhabitants); Annual Incidence of Plasmodium falciparum malaria (AIF) (percentage of positive slides for malaria falciparum/year, in relation to the total of positive slides for malaria); malaria hospitalization rate (number of admissions for malaria/year per thousand inhabitants); malaria mortality rate (deaths due to malaria/year per 100 thousand inhabitants); malaria fatality rate (number of malaria deaths/year per thousand cases of malaria).

The information sources used were the databases and archives of the following; the Epidemiological Surveillance Information System - Notification of Malaria Cases (Malaria-SIVEP), provided by the National Health Foundation (FUNASA) of São Gabriel da Cachoeira; the Information Department of the Brazilian National Health Service (Datasus); the Association of Nursing Workers of São Gabriel da Cachoeira, the institution contracted by the FUNASA; and the Brazilian Institute of Geography and Statistics (IBGE). It is emphasized that the choice of collecting data in the databases and institutional archives was due to the pursuit of accuracy of the information. The inclusion criteria chosen were to work with data validated at the institutional level (FUNASA), within the time period of 2003 to 2007, involving individuals of both sexes and all ages in relation to the variables: API, AIF, malaria hospitalization rate, mortality rate and malaria fatality rate, excluding the other epidemiological variables. Data collection was performed during visits by the researcher to the sites where the sources of information and the data were recorded in forms. All data were stored and analyzed using the free software $\mathrm{R}$ version 2.7.2. The data were submitted to the chisquare test $\left(\chi^{2}\right)$, in order to analyze the distribution of 
the frequencies. The results were considered significant if the $p$-value was $<0.05$.

The study followed the standards of Resolution 196/96, of resolution 304/00, and was approved by the Research Ethics Committee of the Universidade Federal do Amazonas and by the Research Ethics National Commission, registration No. 15100, process No. 25000.179622/2008-56. Along with the project, a request to waiver the Terms of Free Prior Informed Consent was sent, due to this being a study that does not involve the direct participation of human beings.

\section{Results}

The health care model of the municipality of São Gabriel da Cachoeira is inserted into the indigenous healthcare subsystem of the Brazilian National Health Service (SUS), with its services arranged in the form of the Special Indigenous Health District (SIHD) ${ }^{(14)}$. It is part of the Upper Rio Negro SIHD and is divided into nineteen Pole-Bases. According to the data collected in the local network of the FUNASA, activities performed are intra-domicile spraying, in order to protect the residence and thermonebulization, this is performed in nurseries, sites where the vector is encountered after entering the residences, in addition to vector control, the capturing of mosquitoes is also carried out to see if the Anopheles that transmits the disease returned to the focus areas, as well as larval studies. In addition, there is an active search for transmitters, for suspected cases and monitoring of the confirmed cases. The municipality receives antimalarial medication according to the number of cases and insecticide according to a quarterly program. Regarding the human resources, the sector of endemics of the FUNASA/São Gabriel da Cachoeira has a staff of 40 workers, 19 employees of the State, 10 of the Municipality and 11 of the Federal Government, the latter being remnants of the Superintendent of Public Health Campaigns (SUCAM). The funds are transferred monthly from the National Health Fund to the state fund and then to the municipal fund. The numbers of annual cases of malaria during the study period showed that, with the exception of 2004, the majority of the cases of the disease occurred in the rural population, where the greater amount of the population is concentrated, as presented in Table 1.

Table 1 - Number of cases of malaria and Annual Parasite Index in urban and rural areas of São Gabriel da Cachoeira, AM, Brazil, 2003 to 2007

\begin{tabular}{|c|c|c|c|c|c|c|c|}
\hline Area & 2003 & 2004 & 2005 & 2006 & 2007 & Total & p-value \\
\hline \multicolumn{8}{|c|}{ Absolute number of cases } \\
\hline Urban & 507 & 1.066 & 1.496 & 1.020 & 2.527 & 6.616 & $0.000^{*}$ \\
\hline Rural & 510 & 838 & 1.550 & 1.553 & 3.878 & 8.329 & $0.000^{*}$ \\
\hline Total & 1.017 & 1.904 & 3.046 & 2.573 & 6.405 & 14.945 & $0.01^{*}$ \\
\hline \multicolumn{8}{|c|}{ Annual Parasite Index (API) } \\
\hline Urban & 67.7 & 133.8 & 362.0 & 137.7 & 310.1 & - & $0.000^{\dagger}$ \\
\hline Rural & 96.3 & 112.2 & 158.2 & 213.3 & 256.0 & - & $0.000^{+}$ \\
\hline Total & 79.6 & 123.3 & 218.6 & 175.2 & 274.9 & - & $0.000^{+}$ \\
\hline
\end{tabular}

"p-value of the chi-square test, under the null hypothesis that the numbers of malaria cases in each of the areas are equal in the years 2003 to 2007. ${ }^{+} \mathrm{p}$-value of the chi-square test, under the null hypothesis that the APIs in each of the areas are equal.

The annual number of malaria cases has increased over the years for the rural area (Figure 1). Considering the urban area and the total population, there was a period of decline in the number of cases in 2006, breaking the trend of growth. The chi-square test (Table 1) shows that the numbers of cases were significantly different in the years for each of the areas. The boxplot of the cases in the municipality reveals that the distributions by year of the malaria cases are symmetric, presenting variability, being that the year 2003 presents low dispersion. By comparing the cases in the urban and rural areas in relation to the incidence of malaria (Figure 1 ), it is observed that the urban cases are more homogeneous than the rural ones. The boxplot also shows that the highest median is in the rural population cases, as well as the highest dispersion, especially in 2007. 
(a)

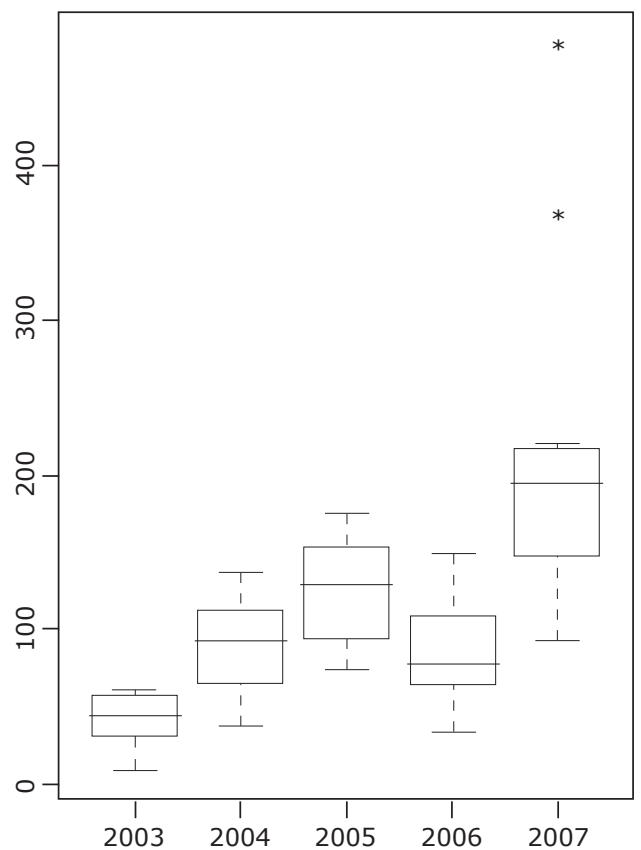

(b)

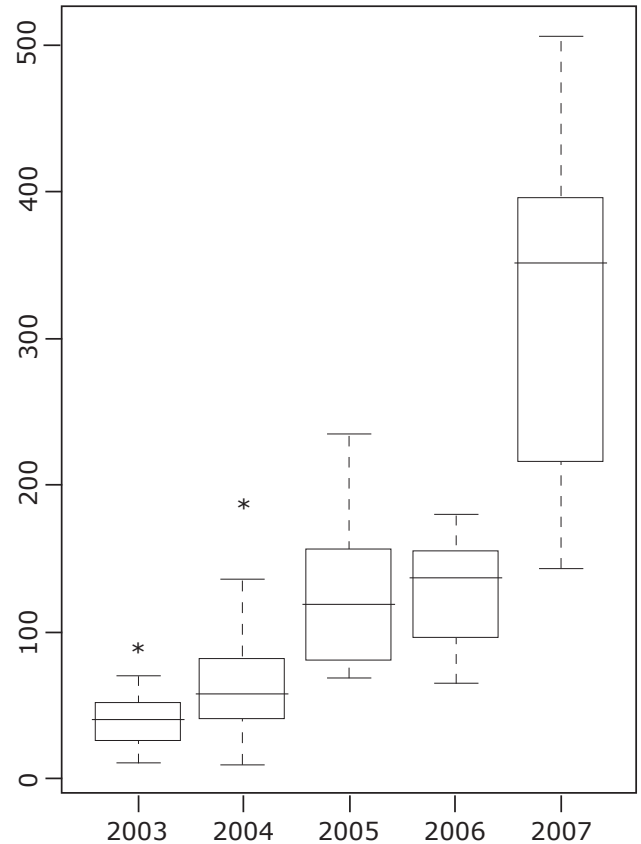

Figure 1 - Boxplot of the distribution of monthly malaria cases per year for: (A) urban area, (b) rural area

The rural area presented a greater number of cases than the urban area, which is shown by the mean number of annual cases. The standard deviation of the rural population is also very large (larger than the urban population), showing great variability in the numbers of cases. This dispersion of values can also be observed when analyzing the amplitude (difference between the maximum and minimum) for the rural area, which is much larger than the urban area (Table 2).

Table 2 - Description of the number of cases of malaria and of the Annual Parasite Index by area, São Gabriel da Cachoeira, AM, Brazil, 2003 to 2007

\begin{tabular}{lcccc}
\hline \multicolumn{1}{c}{ Area } & Median & Mean & Standard Deviation & Amplitude \\
\hline Absolute number of cases & & & & \\
Urban & 1066 & 1323 & 1487.29 & 2020 \\
Rural & 1550 & 1666 & 2581.91 & 3368 \\
Total & 2573 & 2989 & 4030.09 & 5388 \\
Annual Parasite Index (API) & & & & 294.3 \\
Urban & 137.7 & 202.3 & 248.14 & 159.7 \\
Rural & 158.2 & 167.2 & 132.10 & 195.4 \\
Total & 175.2 & 174.3 & 150.72 & \\
\hline
\end{tabular}

The IPA for the rural areas presented a growing trend over the study period (Table 1), while for urban areas and for the total population there was a period of decline in 2006. The chi-square test shows that the APIs are statistically different between the years, within each population. The descriptive analysis of this indicator (Table 2 ) reveals that the urban area presents a mean IPA higher than the rural. The mean IPA of the total population is 174.3 cases/thousand inhabitants. The urban area also presents the highest variability of this indicator, and the highest maximum value, both in the standard deviation and the amplitude, thus demonstrating a greater heterogeneity among the urban area values and a greater homogeneity among the rural area values. Malaria infections with Plasmodium falciparum for the three areas presented decreasing trends over the study period (Table 3), however, in the case of the urban area the proportion of Plasmodium falciparum malaria showed a peak in 2004. The chi-square test shows that Plasmodium falciparum infections are statistically different between the years, within each area. 
Table 3 - Annual proportion of falciparum malaria (AIF), São Gabriel da Cachoeira, AM, Brazil, 2003 to 2007

\begin{tabular}{lccccc}
\hline \multicolumn{1}{c}{ Area } & $\mathbf{2 0 0 3}$ & $\mathbf{2 0 0 4}$ & $\mathbf{2 0 0 5}$ & $\mathbf{2 0 0 6}$ & $\mathbf{2 0 0 7}$ \\
\hline Urban & 13.4 & $17.3(+29.1 \%)$ & $1.1(-93.6 \%)$ & $0.6(-45.5 \%)$ & $0.5(-16.7 \%)$ \\
Rural & 24.1 & $7.5(-68.9 \%)$ & $7.0(-6.7 \%)$ & $5.5(-21.4 \%)$ & $2.3(-58.2 \%)$ \\
Total & 18.8 & $13.0(-30.9 \%)$ & $4.1(-68.5 \%)$ & $3.5(-14.6 \%)$ & 0.000 \\
\hline
\end{tabular}

${ }^{*}$ p-value of the chi-square test, under the null hypothesis that the infections of Plasmodium falciparum malaria in each of the areas are equal.

The numbers of hospital admissions due to malaria in the municipality in the years studied were: 49 (2003), 48 (2004), 61 (2005), 30 (2006) and 41 (2007). Thus, the hospitalization rate for malaria alternated with periods of increase and decrease (Table 4).

Table 4 - Hospitalization, fatality and mortality rates due to malaria, São Gabriel da Cachoeira, AM, Brazil, 2003 to 2007

\begin{tabular}{lccccc}
\hline & $\mathbf{2 0 0 3}$ & $\mathbf{2 0 0 4}$ & $\mathbf{2 0 0 5}$ & $\mathbf{2 0 0 6}$ & $\mathbf{2 0 0 7}$ \\
\hline Hospitalization rate (per thousand inhabitants) & 1.53 & $1.45(-5 \%)$ & $1.79(+23 \%)$ & $0.86(-52 \%)$ & $1.05(+22 \%)$ \\
Mortality rate (per 100 thousand inhabitants) & - & 3.01 & $5.87(+95 \%)$ & $2.87(-51 \%)$ & $5.11(+78 \%)$ \\
Fatality rate (per thousand patients) & - & 0.52 & $0.66(+27 \%)$ & $0.39(-69 \%)$ & $0.31(-21 \%)$ \\
\hline
\end{tabular}

Regarding the number of deaths, in 2003 there were no recorded deaths due to the disease and in the following years the numbers were: 1 (2004), 2 (2005), 1 (2006) and 2 (2007). Consequently, the mortality from malaria also fluctuates in periods of increase and reduction. Furthermore, the fatality rate increased from 2004 to 2005, but thereafter decreased (Table 4).

\section{Discussion}

São Gabriel da Cachoeira can be considered a unique municipality because it is the third largest municipality of Brazil in land area, virtually all of its territory is made up of indigenous lands, $80 \%$ of the 15,000 inhabitants of the urban area are considered indigenous and the rural area is predominantly formed by indigenous communities, comprising a total of $90 \%$ of the indigenous population of the municipality ${ }^{(11,15)}$. There are 34 SIHDs throughout the country, which can be defined as "a model of organization of services, which address a set of technical activities, aimed at rationalized and qualified healthcare measures, promoting the reorganization of the health network and the sanitary practices and the development of administrative and management activities necessary for providing care, with social participation"(16). This model was implemented in Brazil in 1991, with Decree No. 23, assigning the responsibility for Indigenous health, formerly assigned to the FUNAI (Ministry of Justice), to the Ministry of Health (FUNASA). The first SIHD created was directed towards the Yanomami people. In 1994, the coordination of health actions returned to the FUNAI, being returned to FUNASA in 1999. The care model of regionalization, endorsed by the II National
Conference on Health for Indigenous Peoples of 1993, which refers to social participation, was retained by the FUNASA(17). However, the direct implementation of the health activities in the indigenous areas started to be performed through partnerships with indigenous organizations, Nongovernmental organizations (NGOs), health secretariats and universities ${ }^{(14)}$. The SIHD of the Upper Rio Negro began to be implemented in 1999 as an initiative of some social segments, including the Municipal Health Secretariat, the Federation of Indigenous Organizations of the Rio Negro (FOIRN), the Diocese of the Rio Negro, the Health Without Limits NGO, the Association of Nursing Workers of São Gabriel da Cachoeira (ATESG), the Association of Indigenous Health Agents of the Upper Rio Negro, the Army Garrison Hospital and the Institute for Sanitary Development ${ }^{(12,18)}$.

Since 2003, the NGO contracted to provide health services in the area of São Gabriel da Cachoeira was FOIRN, which also promotes activities of education, selfsupport, autonomy and indigenous culture valorization. With the new responsibilities, there was a disproportion in the investment in the other areas of the FOIRN. The role of health services provider brought the difficulty in reconciling the roles of "militant organization" and "professional organization", due to the other priorities of the institution being unbalanced(17). In 2008, the FUNASA signed an agreement with ATESG giving them the responsibility to contract human resources physicians, nurses, odontologists, nursing technicians, health agents etc, to purchase continuous and controlled use medications, office materials, medical, nursing and 
odontological supplies, didactic material, and parts for outboard engines and vehicles, among others.

The SIHD of the Upper Rio Negro serves 605 communities, which are visited monthly by a professional team. Their pole-bases encompass 15 to 110 locations, covering a population of 600 to 2,800 individuals each. Their health teams are composed of one nurse, a physician, three nursing technicians, an odontological assistant, one dentist for every two pole-bases and approximately ten indigenous health agents for each area(18). The radiophone is the means of communication used. Some pole-bases are in locations of difficult access, reached only after days of walking or by helicopter, which makes continuous work impossible, in accordance with the monthly program. Shortly before the deployment of the PIACM, the process of decentralization of health surveillance began for certified states and municipalities. Thus, there was an institutional reorganization, so that the workers of the FUNASA were incorporated into the state and municipal health secretariats(19). It was observed in São Gabriel da Cachoeira that the FUNASA sector of Epidemics is staffed by workers of the municipality, the State and the Federal Government working in malaria control. In the municipality studied, the majority of malaria control actions are carried out as recommended by the NMPCP(10), however, it is necessary to continue the work already being carried out, making the effort permanent and broadening the scope of the goals proposed by the program so that control of the disease can be achieved, maintaining it at reduced levels. Some factors that influence the effectiveness of the implementation of the actions of health professionals are: the lack of outboard motors, aluminum boats (airboats) and generators in perfect working order, delays in releasing financial resources by FUNASA, consequently causing delays in implementing the health programs and the payment of the health professionals.

The results of this study are similar to those found in a study on malaria in the middle Rio Negro, where an even greater variation in increases and decreases in the numbers of annual cases was detected ${ }^{(20)}$, and those found in a study in the state of Rondônia(21), where the majority of cases also occurred in rural areas. As the transmission and endemicity of malaria in the Brazilian Amazon is considered to be of low and medium intensity and as the area is one of unstable transmission ${ }^{(20)}$, the control actions must be constant in their vigilance, as these characteristics make the area prone to seasonal epidemics, which may explain the variation found in the numbers. The API is the indicator that estimates the risk of annual cases and expresses the degree of risk for malaria transmission as low ( $<10.0$ cases/ thousand inhabitants), medium (10.0 to 49.9 cases/ thousand inhabitants) and high ( $\geq 50.0$ cases/thousand inhabitants)(22). São Gabriel da Cachoeira presented a very high risk for malaria transmission, with the lowest API of 79.6 cases/thousand inhabitants and the highest reaching 274.9 cases/thousand inhabitants. The API followed the trend in the number of cases, as might be expected, presenting an increase over the years, with the exception of 2006. However, unlike the number of cases, the highest APIs were recorded in the urban area (Table 1), similarly to studies performed in the Middle Rio Negro(20) and the state of Rondônia(21), and differing from another study conducted in the state of Mato Grosso(23), which found that although an increasing API was found in the State of Mato Grosso in the early years of their study, in the final period a decline in this trend was observed.

The increasing propensity of the reports of the disease, indicated by the malaria control actions, in the municipality studied can be attributed both to the strategies supplied by the programs for the monitoring services that provide a broader detection capacity, as well as to the population increase observed over the years. The proportion of malaria caused by $P$. falciparum in Sao Gabriel da Cachoeira presented a decline over the years studied (Table 3 ). On one hand, this reduction can be attributed to the control measures developed in the city, such as expanding the network of laboratories and active searches, allowing early diagnosis and treatment, on the other, there is the influence of the increase in cases caused by Plasmodium vivax, since the AIF is the ratio of positive slides for Plasmodium falciparum to the total of positive slides, results consistent with other studies $^{(20-21)}$. The number of hospitalizations represents an estimate of the clinical severity of the disease in the population. The hospitalization rate due to malaria presented variations of increase and decrease in Sao Gabriel da Cachoeira throughout the study period (Table 4). This differs in part from the study that also found a significant reduction in the number of hospitalizations in the state of Rondônia(21). It relates the reduction in the number of hospitalizations to the expansion of the laboratory network, which occurred mainly during the term of the PIACM.

In 2003 there were no deaths due to malaria in the municipality studied. In the subsequent years, both the mortality rate and the fatality rate presented 
variations of highs and lows (Table 4). Fluctuations in the trend of these rates were also observed in other studies $^{(21,23)}$. Such studies highlight the occurrence of an typical epidemic process, with the increase in morbidity, mortality and fatality coinciding with the increased flow of migrants, the emerging structure of the health services, the difficulty of access, both of the individuals to health services and of the professionals to sites of colonization, the presence of miners, of asymptomatic individuals and environmental conditions favorable to the vector. These characteristics are also present in the municipality of this study. São Gabriel da Cachoeira is one of 22 Amazonian municipalities that contributed $80 \%$ of the cases of the disease in the state ${ }^{(8,24)}$. In malaria control, intersectoral collaboration between the health sector and other public agencies is of fundamental importance, as is the commitment of all social actors involved in the provision of health services at all levels of care, strengthening the local health services(19).

\section{Conclusions}

With this study on the care actions of malaria control to the indigenous population of São Gabriel da Cachoeira, it is concluded that there was a significant increase in malaria cases and an increasing incidence of API in the rural areas. The occurrence of fluctuations in the mortality and fatality rates was observed over the time period studied. The actions of malaria control work in accordance with the NMPCP. Therefore, the actions of malaria control in San Gabriel proved to be effective, given that there was a reduction of Plasmodium falciparum infections, of hospital admissions and of deaths from the malaria disease, however, the number of cases and the API increased over the years 2003 to 2007. Finally, a limitation of the study is the possibility of underreporting of the malaria disease in the records of the Health Information System of the Brazilian National Health System (SUS).

\section{Acknowledgements}

To Isabel Gomes for the statistical analysis; to the professor Maria Jacirema Ferreira Gonçalves for the suggestions in the review; to the Municipal Health Secretariat of São Gabriel da Cachoeira, FUNASA/São Gabriel da Cachoeira, DSEI of the Alto Rio Negro and the Amazonas Research Foundation/Coordination for the Improvement of Higher Education Personnel (FAPEAM/ CAPES) for financial support.

\section{References}

1. World Health Organization [Internet]. Malaria. Fact Sheet 94. Washington: WHO; 2007. [acesso 27 set 2007]. Disponível em: http://who.int/inf-fs/en/fact094.html

2. Almeida LB, Barbosa MGV, Martinez-Espinosa FE. Malária em mulheres de idade de 10 a 49 anos, segundo o SIVEP- Malária, Manaus, Amazonas, 2003-2006. Rev Soc Bras Med Trop. 2010;43(3):304-8.

3. Alecrim WD, Gonçalves MJF. Non-planned Urbanization as a contributing factor for malaria incidence in Manaus - Amazonas, Brazil. Rev Salud Pública. 2004;(6):156-66.

4. Osorio-de-Castro CGS, Miranda ES, Esher A, Campos MR, Brasil JC, Ferreira ACS, et al. Conhecimentos, práticas e percepções de profissionais de saúde sobre o tratamento de malária não complicada em municípios de alto risco da Amazônia Legal. Ciênc Saúde Coletiva. 2011;16(suppl.1):1445-56.

5. Tadei WP, Dutary-Thatcher B. Malária na Amazônia Brasileira: Anopheles do subgênero Nyssorhynchus. Rev Inst Med Trop S Paulo. 2000;42(2):87-94. Inglês.

6. Confalonieri U. Saúde na Amazônia: um modelo conceitual para a análise de paisagens e doenças. Estud Av. 2005;19(53):221-36.

7. Escobar AL, Santos R, Coimbra-Jr CEA. Avaliação nutricional de crianças indígenas Pakaanóva (Wari'), Rondônia, Brasil. Rev Bras Saúde Matern Infant. 2003;3(4):457-61.

8. Ministério da Saúde (BR). Secretaria de Vigilância em Saúde. Plano de Intensificação das Ações de Controle da Malária na Amazônia Legal (PIACM) período julho de 2000 a dezembro de 2002: relatório de gestão. Brasília (DF): Ministério da Saúde; 2003.

9. Tauil PL. Avaliação de uma nova estratégia no controle da malaria na Amazônia Brasileira. Rev Inst Med Trop S Paulo. 2003;45(6):306-6. Inglês.

10. Brasil. Ministério da Saúde. Programa Nacional de Prevenção e Controle da Malária PNCM. Brasília (DF): Ministério da Saúde; 2003.

11. Giatti LL, Rocha AA, Toledo RF, Barreira LP, Rios L, Pelicioni MCF, et al. Condições Sanitárias e socioambientais em Iauaretê, área indígena em São Gabriel da Cachoeira, AM. Ciênc Saúde Coletiva. 2007;12(6):1711-23.

12. Levino A, Oliveira RM. Tuberculose na população indígena de São Gabriel da Cachoeira, Amazonas, Brasil. Cad Saude Publica. 2007;23(7):1728-32.

13. Arreaza ALV, Moraes JC. Contribuição teórico-conceitual para a pesquisa avaliativa no contexto de vigilância da saúde. Ciênc Saúde Coletiva [periódico na Internet]. 
2010 [acesso 9 jul 2011]:15(5):2627-38. Disponível em: http://www.scielosp.org/scielo.php?pid=S141381232010000500037\&script=sci_arttext

14. Athias R, Machado M. A Saúde Indígena no Processo de Implantação dos Distritos Sanitários: temas críticos e propostas para um diálogo interdisciplinar. Cad Saúde Pública. 2001;17(2):425-31.

15. Eloy L. Diversidade alimentar e urbanização: o papel das migrações circulares indígenas no Noroeste Amazônico. Antropology of Food. [Internet]. 2009. [acesso 9 jul 2011]. Disponível em: http://aof.revues. org/index6444.html

16. Fundação Nacional de Saúde (BR). Política Nacional de Atenção à Saúde dos Povos Indígenas. $2^{a}$ ed. Brasília (DF): Ministério da Saúde. Fundação Nacional de Saúde; 2002.

17. Garnelo L, Sampaio S. Organizações Indígenas e Distritalização Sanitária: os riscos de "fazer ver" e "fazer crer" nas políticas de saúde. Cad Saúde Pública. 2005;21(4):1217-23.

18. Amarante JM, Costa VLA, Monteiro J. O controle da tuberculose entre os índios Yanomami do Alto Rio Negro. Bol Pneumol Sanit. 2003;11(2):5-12.

19. Ladislau JLB, Leal MC, Tauil PL. Avaliação do Plano de Intensificação das Ações de Controle da Malária na região da Amazônia Legal, Brasil, no contexto da descentralização. Epidemiol Serv Saude. 2006;15(2):9-20.

20. Suárez-Mutis M, Coura J. Mudanças no Padrão Epidemiológico da Malária em Área Rural do Médio Rio Negro, Amazônia. Cad Saúde Pública. 2007;23(4):795-804.

21. Rodrigues AF, Escobar AL, Souza-Santos R. Análise espacial e determinação de áreas para o controle da malária no Estado de Rondônia. Rev Soc Bras Med Trop. [periódico na Internet]. 2008 [acesso 9 jul 2011];41(1):55-64. Disponível em: http://www. scielo.br/scielo.php?script $=$ sci_arttext\&pid $=$ S003786822008000100011 \&lang $=$ en

22. Rede Interagencial de Informações para a Saúde. Indicadores Básicos de Saúde no Brasil: conceitos e aplicações. Brasília (DF): Organização Pan-Americana da Saúde; 2002.

23. Atanaka-Santos M, Czeresnia D, Souza-Santos R, Oliveira R. Comportamento epidemiológico da malária no Estado de Mato Grosso, 1980-2003. Rev Soc Bras Med Trop. [periódico na Internet]. 2006 [acesso 9 jul 2011];39(2):187-92. Disponível em: http://www. scielo.br/scielo.php?script $=$ sci_arttext\&pid $=$ S003786822006000200011
24. Ministério da Saúde/SVS (BR). Sistema Nacional de Vigilância em Saúde: Relatório de Situação: Amazonas. 3. ed. Brasília (DF): Ministério da Saúde; 2007.
Received: Dec. $22^{\text {nd }} 2010$ Accepted: Sept. $20^{\text {th }} 2011$ 